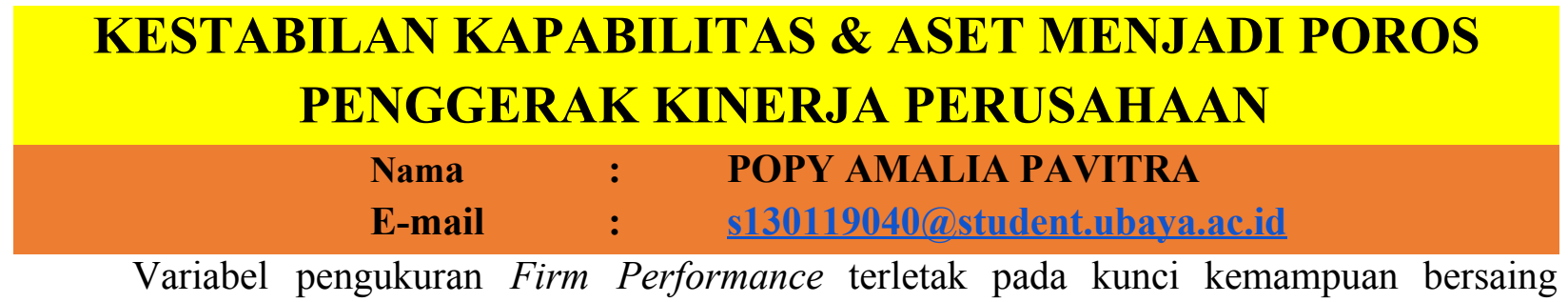
perusahaan yang meliputi termasuk Kemampuan Inovasi (Kemampuan Proses Inovasi \& Kemampuan Produk Inovatif), Kinerja Inovasi (Kecepatan Inovasi \& Kualitas Inovasi), dan Kinerja Fungsional (Kinerja Manufaktur \& Kinerja Pemasaran). Indikator pengukuran Firm Performance terletak pada akuisisi pelanggan baru, meningkatkan penjualan ke pelanggan saat ini, pertumbuhan total pendapatan penjualan, tingkat harga absolut, kekuatan harga di pasar, profitabilitas unit bisnis, laba atas penjualan (ROS), dan laba atas investasi (ROI) yang menjadi pengujian beberapa responden. Selain itu pengembangan kepercayaan organisasi, penerapan harga kapabilitas, dan perubahan organisasi merupakan dimensi ukuran kinerja perusahaan yang paling penting dengan pasar yang memiliki pengaruh signifikan. Untuk pengujian ukuran kinerja perusahaan kami menggunakan metode analisis tidak langsung bersyarat dengan hasil akhir berupa presentase seperti pada pengaruh estimasi CSR yang lebih kuat ketika inovasi perusahaan intensitas lebih tinggi (Hayes \& Rockwood 2020). Pemodelan secara konseptual pada Firm Performance ini harus paham mengenai kemampuan perencanaan untuk keseimbangan keberlanjutan pemasok serta keberlanjutan lingkungan baik internal maupun eksternal yang mempengaruhi kemampuan perusahaan.

Dengan pendekatan subyektif aspek-aspek pada Firm Performance ini meliputi Perbandingan Pertumbuhan dengan Pesaing Langsung, ROA, ROI, Gross Profit, dan Growth Employement. Untuk mencapai kinerja perusahaan yang terbaik adalah dengan menstabilkan Turbalency Technologi dengan perilaku proaktif (Pratono 2016). Membahas tentang Green Entreprebeurial Orientation (Pengambilan Resiko, Agresivitaas Kompetitif, dan Inovatif) dan Market Orientation (RanD) menjadi sebuah variable independen yang berdampak positif pada Competitive Advantage (ROI) yang menyangkut pangsa pasar (Pratono 2019). 


\section{DAFTAR PUSTAKA}

Ahmed, W., Najmi, A., \& Ikram, M. (2020). Steering firm performance through innovative capabilities: A contingency. Technology in Society, (63) 101385.

Liozu, S. M., \& Hinterhuber, A. (2013). The Confidence Facor in Pricing : Driving Firm Performance. Journal Of Business Strategy, 34.

Liu, Y., Lei, L., \& Buttner, E. (2020). Establishing the boundary conditions for female board directors' influence. Journal of Business Reasearch, (121) 112-120.

Pratono, A. H. (2016). Strategic orientation and information technological turbulence: Contingency perspective in SMEs. Business Process Management Journal, (22)368-382.

Pratono, A. H., Darmasetiawan, N. K., Yudiarso, A., \& Jeong, B. G. (2019). Achieving Sustainable Competitive Advantage through Green Entrepreneurial Orientation and Market Orientation : The Role of Inter-Organizational Learning. The Bottom Line, (32) $2-15$.

Sardana, D., Gupta, N., Kumar, V., \& Terziovski, M. (2020). CSR 'sustainability’ practices and firm performance in an emerging. Journal of Cleaner Production, (258) 120-766. 